\title{
TRACER STUDY PADA PROGRAM STUDI S1 TEKNOLOGI PANGAN UNIVERSITAS TERBUKA
}

\author{
Dini Nur Hakiki, Athiefah Fauziyyah, Eko Yuliastuti \\ Universitas Terbuka (UT) Jakarta, Indonesia \\ Email: dini-hakiki@ecampus.ut.ac.id, athiefah.fauziyyah@ecampus.ut.ac.id, \\ eko@ecampus.ut.ac.id
}

Received: 2020-02-15; Accepted: 2020-03-05; Published: 2020-03-15

\begin{abstract}
Abstrak
Telah dilakukan tracer study program studi teknologi pangan 2017-2020 menggunakan metode kualitatif (qualitative research) melalui survei dan wawancara dengan variable (1) keterserapan alumni di dunia kerja (2) Kontribusi Perguruan tinggi terhadap tingkat komptensi yang dikuasai (3) Penilaian alumni terhadap metode pembelajaran di PS teknologi Pangan. Hasil tracer study menyatakan bahwa dari segi keterserapan alumni di dunia kerja, alumni UT 68\% sudah bekerja dan sebanyak $70 \%$ sudah memperoleh pekerjaan sebelum masuk UT. Bidang pekerjaan alumni paling banyak di bidang swasta di sektor usaha makanan dan minuman. Kontribusi Perguruan tinggi terhadap tingkat kompetensi yang dikuasai alumni yaitu lebih dari 50\% alumni menyatakan perguruan tinggi berkontribusi sangat tinggi dan tinggi dalam pengetahuan di bidang ilmu teknologi pangan, kemampuan riset dan analisis, komunikasi, ketrampilan digital, manajemen waktu dan kemampuan dalam memegang tanggung jawab, serta sof skill. Penilaian alumni terhadap metode pembelajaran di PS Teknologi Pangan.yaitu lebih dari 50\% menyatakan sudah sangat baik dan baik dari tutorial online, praktikum, dan bahan ajar cetak. Masukan alumni untuk perbaikan layanan yaitu untuk tutorial online perlunya peningkatan server, tampilan yang lebih menarik, penambahan video dan studi kasus, serta tutor yang perlu lebih aktif, untuk praktikum yaitu perlunya laboratorium sendiri yang dimiliki oleh UT, mata kuliah praktikum perlu diperbanyak, serta integrasi mata kuliah praktikum dengan dengan mata kuliah lain, dan untuk untuk bahan ajar cetak perlu dilakukan pembaharuan materi yang mengikuti dengan perkemabangan teknologi dan ilmu pengetahuan.
\end{abstract}

Kata kunci: study; teknologi pangan; program studi

\begin{abstract}
Tracer study program in food technology 2017-2020 has been conducted using qualitative research methods through surveys and interviews with variable (1) the availability of alumni in the world of work (2) The contribution of universities to the level of competition mastered (3) Alumni assessment of learning methods in food technology. The results of the tracer study stated that in terms of the availability of alumni in the world of work, UT alumni $68 \%$ have worked and as many as $70 \%$ have obtained jobs before entering UT. The field of work of most alumni in the private sector in the food and beverage business sector. The contribution of the College to the level of competence mastered by alumni, which is more than $50 \%$ of alumni stated that the college contributes very high and high in knowledge in the field of food technology science, research and analysis skills, communication, digital skills, time management and the ability to hold responsibilities, and skills. Alumni assessment of learning methods at PS Teknologi Pangan., which is more than 50\% stated that it is very good and good from online tutorials, practicums, and printed teaching materials. Alumni input for service improvement is for online tutorials for server improvement, more attractive display, addition of video and case studies, as well as tutors who need to be more active, for practicums that are the need for their own laboratories owned by UT, practicum courses need to be expanded, as well as the integration of
\end{abstract}


practicum courses with other courses, and for print teaching materials need to be updated materials that follow with technological development and science.

Keywords: study; food technology; study program

\section{PENDAHULUAN}

Menurut Blackwell dan Miniard pengetahuan dijadikan sebagai informasi yang disimpan seseorang di dalam memori otaknya, sebagian informasi tersebut berfungsi bagi konsumen untuk mengenali pasar, dan hal tersebut disebut sebagai pengetahuan konsumen (Pasi, 2019). Sama halnya dengan pengetahuan keterampilan merupakan kapasitas yang dibutuhkan untuk melaksanakan tugas. Kerampilan merupakan pengembangan hasil training dan pengalaman yang didapat (Hartinah \& Abdullah, 2019).

Program Studi Teknologi Pangan Universitas Terbuka telah berdiri hampir 15 tahun dan telah meluluskan ratusan alumni yang tersebar dari Sabang hingga Merauke. Alumnialumni ini tentunya akan ditunggu kiprahnya di masyarakat. Perguruan Tinggi memiliki tanggung jawab kepada masyarakat melacak para alumninya guna mengetahui kinerja dan kemampuan alumninya. Pertanyaan yang akan sering muncul setelah seseorang menyelesaikan jenjang pendidikan tinggi ialah kerja apa, di mana, untuk siapa, dan kinerjanya seperti apa (Dini, Fauziyyah, \& Yuliastuti, 2020). Pertanyaan ini merupakan parameter bahwa pengetahuan dan keterampilan yang didapat semasa di perguruan tinggi dapat bermanfaat bagi masyarakat melalui karya nyata alumninya. Salah satu cara untuk melacak keberadaan dan kiprah alumni setelah meninggalkan Perguruan Tinggi, terutama terkait untuk menggali infomasi berkaitan dengan transisi dari kuliah kepekerjaan adalah dengan melaksanakan suatu studi yang dikenal dengan tracer study (Bakhri \& Jumena, 2019).

Tracer study merupakan studi pelacakan jejak lulusan/alumni yang dilakukan sekitar 13 tahun setelah lulus. Tracer study bertujuan untuk mengetahui outcome pendidikan dalam transisi dari dunia pendidikan tinggi ke dunia kerja, output pendidikan yaitu penilaian diri terhadap penguasaan dan pemerolehan kompetensi, proses pendidikan berupa evaluasi proses pembelajaran dan kontribusi pendidikan tinggi terhadap pemerolehan kompetensi, input pendidikan berupa penggalian lebih lanjut terhadap informasi sosiobiografis lulusan (Terkemuka, Unggul, \& pada Tahun, 2016).

Tracer study oleh program studi Teknologi Pangan telah dilakukan pada tahun 2018 dan telah mendata 36 orang dari 86 alumni yang telah lulus dari masa registrasi 2005.1 hingga 2018.1. Data tracer study tersebut terdiri dari penilaian alumni mengenai mutu dan penyelenggaraan program studi, penilaian stakeholders terhadap kinerja alumni, lama masa tunggu alumni sampai mendapatkan pekerjaan atau naik ke jenjang karir yang lebih tinggi, dan relevansi antara kurikulum dengan kebutuhan di lapangan. Selama akhir tahun 2018 juga telah terjadi perubahan di kurikulum program studi Teknologi Pangan yaitu penghapusan mata kuliah tertentu dan penambahan mata kuliah baru. Pada Tahun 2019, tracer study belum dilakukan. Padahal pada tahun 2020, seiring dengan perubahan revolusi industri 4.0, PS Teknologi Pangan berencana melakukan reanalisis kurikulum agar profil lulusan memiliki capaian pembelajaran lulusan yang selaras dengan kebutuhan tenaga kerja di era revolusi industri 4.0.

Oleh karena itulah perlu dilakukan update data tracer study meliputi masa tunggu lulusan sampai mendapatkan pekerjaan, kepuasaan stakeholders atas kinerja alumni, pengembangan wawasan keilmuan alumni, keterampilan alumni di dunia kerja, kepuasan alumni atas layanan pendidikan yang diberikan program studi selama mereka mengikuti 
pendidikan, maupun kepuasan dan kebutuhan stakeholder dengan kesesuaian kurikulum pada program studi yang ditempuh alumni.

Data tracer study ini nantinya dapat digunakan untuk keperluan pengembangan kurikulum baru, pemenuhan standar pada evaluasi diri dan borang pada proses akreditasi program studi. Selain itu, data ini dapat digunakan untuk untuk mengetahui seberapa besar tingkat daya serap pasar terhadap lulusan, berapa jumlah pengangguran lulusan, kesesuaian antara kompetensi mata kuliah dengan kebutuhan lapangan, dan lain-lain.

\section{METODE PENELITIAN}

Tracer study PS S-1 Teknologi Pangan FST UT dilakukan menggunakan metode kualitatif (qualitative research) melalui survei dan wawancara yang melibatkan lulusan dan pengguna lulusan sebagai sumber datanya. Teknik analisis data menggunakan deskriptif prosentase. Populasi adalah seluruh lulusan PS Teknologi Pangan pada kohort (batasan target lulusan/alumni yang akan disurvei) 4 tahun kebelakang, yaitu lulusan tahun 2020 hingga 2017. Jumlah jumlah sample mahasiswa lulusan tahun 2017, 2018, 2019, dan 2020 dikirimkan kuisoner tracer study baik melalui email maupun wa blast.

Variabel penelitian ini meliputi: (1) keterserapan alumni di dunia kerja (2) Kontribusi Perguruan tinggi terhadap tingkat komptensi yang dikuasai (3) Penilaian alumni terhadap metode pembelajaran di PS teknologi Pangan.

\section{HASIL PENELITIAN DAN PEMBAHASAN}

\section{Karakteristik Data Alumni}

Alumni PS Teknologi pangan yang mengisi kuesioner berjumlah 37\% laki-laki (dan $63 \%$ perempuan. Dari segi usia lebih dari $70 \%$ responden alumni berusia antara 20-30 tahun, dan sisanya berusia 30-40 tahuan. Jumlah alumni yang disurvei paling banyak berasal dari angkatan 2020 yaitu 37\%, kemudian Angkatan 2019 sebanyak 33\%, dan sisanya Angkatan 2018 dan 2017 sebanyak 20\% dan 11\% (Tabel 1).

Tabel 1

Almni berdasarkan angkatan tahun

\begin{tabular}{cc}
\hline Tahun Angkatan & Jumlah \\
\hline 2017 & $11 \%$ \\
\hline 2018 & $20 \%$ \\
\hline 2019 & $33 \%$ \\
\hline 2020 & $37 \%$ \\
\hline
\end{tabular}

Lama studi mahasiswa yang dapat menyelesaikan kurang dari 4 tahun sebanyak $35 \%$, lulus tepat waktu selama 4 tahun sebanyak $35 \%$, dan hanya $6 \%$ yang lulus lebih dari 8 tahun. PS Teknologi Pangan menerima mahasiswa alih kredit yang masa tempuh studinya memunginkan masa studi kurang dari 4 tahun. Rata-rata IPK alumni paling banyak berada pada rentang 2,5-3 (Gambar 1). 

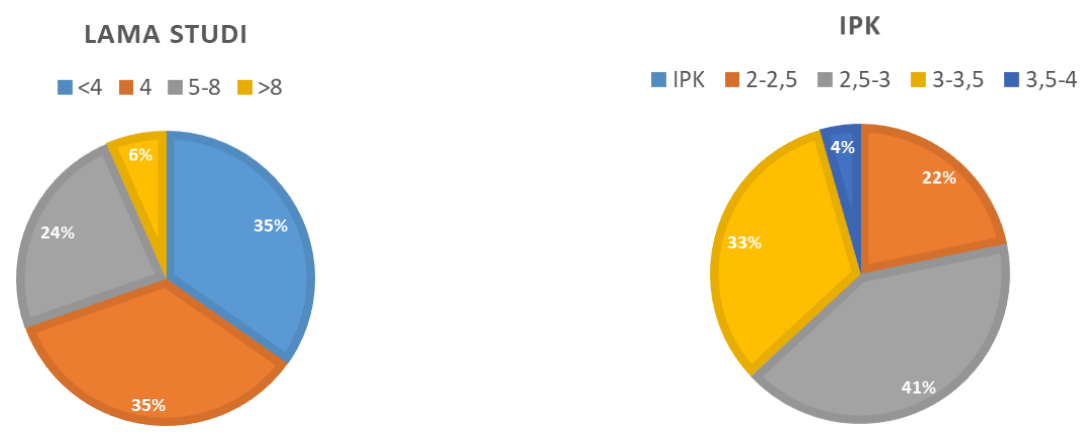

\section{Gambar 1}

\section{Lama studi dan nilai IPK alumni PS Teknologi Pangan}

\section{Keterserapan Alumni Di Bidang Kerja}

Ditinjau dari status bekerja, sebanyak 68\% alumni PS Teknologi Pangan berstatus bekerja, $15 \%$ berwirausaha sedangkan $17 \%$ belum bekerja. Alasan alumni yang Alumni yang tidak bekerja adalah masih menunggu lamaran kerja dan mengurus keluarga. Lebih dari $70 \%$ alumni sudah mendapatkan pekerjaan sebelum masuk ke UT, sebanyak $23 \%$ sudah mendapatkan pekerjaan kurang dari 3 bulan dan $7 \%$ mendapatkan pekerjaan pada rentang waktu 3-6 bulan. Informasi pekerjaan paling banyak didapatkan melalui internet/iklan, kemudian melalui relasi, membangun jejaring, dan melamar ke perusahaan tanpa mengetahui lowongan. Kemudian pertanyaan mengenai berapa lamaran yang dikirimkan untuk mendapatkan pekerjaan pertama, alumni menjawab yaitu mulai hanya 1 lamaran hingga ada yang 250 lamaran. Dari lamaran tsb sekitar 50\% lamaran tsb direspon, dan berlanjut ke wawancara. Sebaran alumni berdasarkan status pekerjaan dan info mendapatkan pekerjaan ditampilkan pada Gambar 2 berikut.

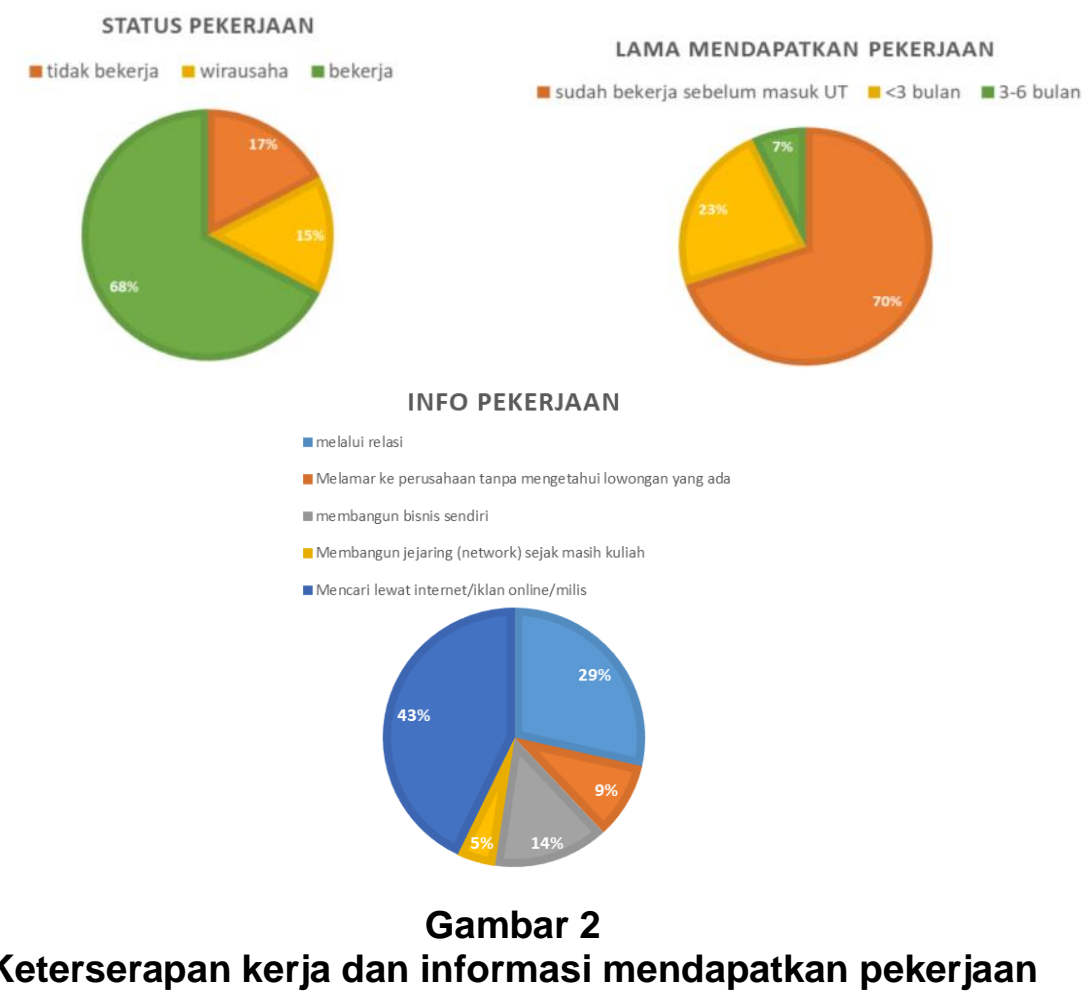

Ditinjau dari bidang pekerjaannya, sebanyak 64\% alumni PS Teknologi Pangan bekerja sebagai karyawan swasta di perusahaan nasional/multinasional, 17\% bekerja 
pemerintahan, $17 \%$ di wiraswasta, dan 2\% di LSM. Dilihat dari segi sektor pekerjaan sebagian besar bekerja di bidang industri makanan dan minuman, kemudian terbesar kedua dari sektor pendidikan, dilanjutkan dengan farmasi dan kesehatan dan sisanya di bidang consumer goods, perdagangan, proporti, lingkungan, industri dasar dan kimia, serta pertanian. Sebaran alumni berdasarkan bidang pekerjaan ditampilkan pada Gambar 3 berikut.
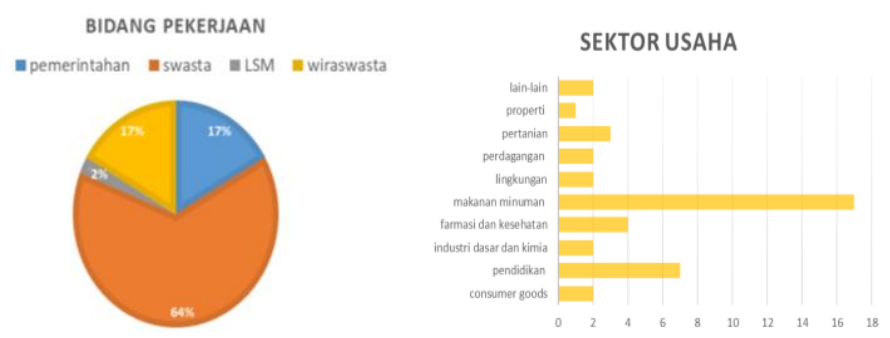

\section{Gambar 3 \\ Alumni PS Teknologi Pangan berdasarkan bidang pekerjaan}

Terkait dengan kesesuaian pekerjaan alumni dengan harapan ketika belajar di PS Teknologi Pangan FST UT, sebanyak 48\% responden alumni PS Teknologi Pangan FST UT menyatakan bahwa pekerjaan mereka saat ini sangat erat kaitanya dengan PS Teknologi Pangan. Sebanyak 12\% responden menyatakan bahwa pekerjaan mereka saat ini kurang sesuai dengan harapan ketika belajar di PS Teknologi Pangan dan 21\% lainnya menyatakan tidak sesuai. Selanjutnya dari tingkat kesesuaian Pendidikan dengan pekerjaan saat ini, sebanyak $61 \%$ menyatakan bahwa pekerjaan yang dijalani saat ini sudah sama dengan tingkat pendidikan yang dibutuhkan, sebanyak $23 \%$ lainnya menyatakan setingkat lebih tinggi, dan hanya $9 \%$ setingkat lebih rendah. Kesesuaian pekerjaan alumni ditampilkan pada Gambar 4.
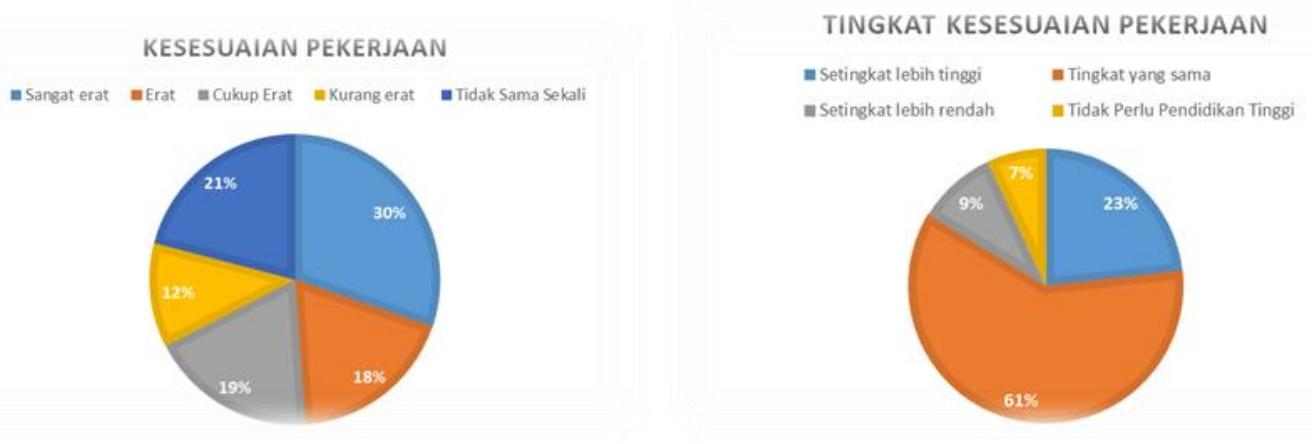

\section{Gambar 4 \\ Kesesuaian pekerjaan alumni PS Teknologi Pangan}

\section{Kontribusi Perguruan Tinggi terhadap Tingkat Komptensi yang dikuasa}

Berdasarkan hasil kuisoner, kontribusi perguruan terhadap kompetensi mahasiswa dapat dilihat dari 28 aspek yang dibagi menjadi ranah pengetahuan, keterampilan digital, negosiasi dan komunikasi, kemampuan riset dan analisis, kemampuan manajerial, dan softskill (Gambar 5).

Dari ranah pengetahuan, lebih dari $70 \%$ menilai kontribusi perguruan tinggi dalam memberikan pengetahuan di bidang atau disiplin ilmu sangat tinggi dan tinggi, namun dari segi pengetahuan di luar bidang ilmu, pengetahuan umum, dan kemampuan bahasa 
inggris lebih dari setengahnya menjawab cukup berkontribusi. Di bidang riset dan analisis lebih dari $60 \%$ menjawab kontribusi pergutuan tinggi sangat tinggi dan tinggi. Kemampuan berpikir kritis memiki persentae paling tinggi dalam memberikan kontribusi, kemudian disusul dengan kemampuan belajar mandiri, kemampuan memecahkan masalah, kemampuan belajar sepanjang hayat, kemampuan riset, dan kemampuan analisis. Dalam segi keterampilan digital lebih dari $60 \%$ alumni menayatakan perguruan tinggi berkontribusi terhadap keterampilan komputer dan internet (Adib, 2011).

Peran perguruan tinggi dalam memberikan keterampilan komunikasi dan negosiasi alumni yaitu sebanyak $48 \%$ menyatakan cukup perguruan tinggi dalam memberikan ketrampilan negosiasi, dan 55\% menyatakan sangat tinggi dan tinggi peran perguruan tinggi dalam memberikan kemamapuan komunikasi. Dari segi kemampuan dalam bekerja, lumni memperoleh kemampuan bekerja secara mandiri yang signifikan ditunjukan lebih dari $80 \%$ menjawab sangat tinggi dan tinggi. Kemampuan manajerial yang paling menonjol menurut alumni adalah dalam segi manajemen waktu dan kemampuan dalam memegang tanggung jawab (Nasir \& Rijal, 2020). Terakhir dari segi soft skill perguruan tinggi lebih dari $65 \%$ menyatakan perguruan tinggi berkontribusi dari segi toleransi, loyalitas, integritas, inisiatif, dan kemampuan adaptasi.
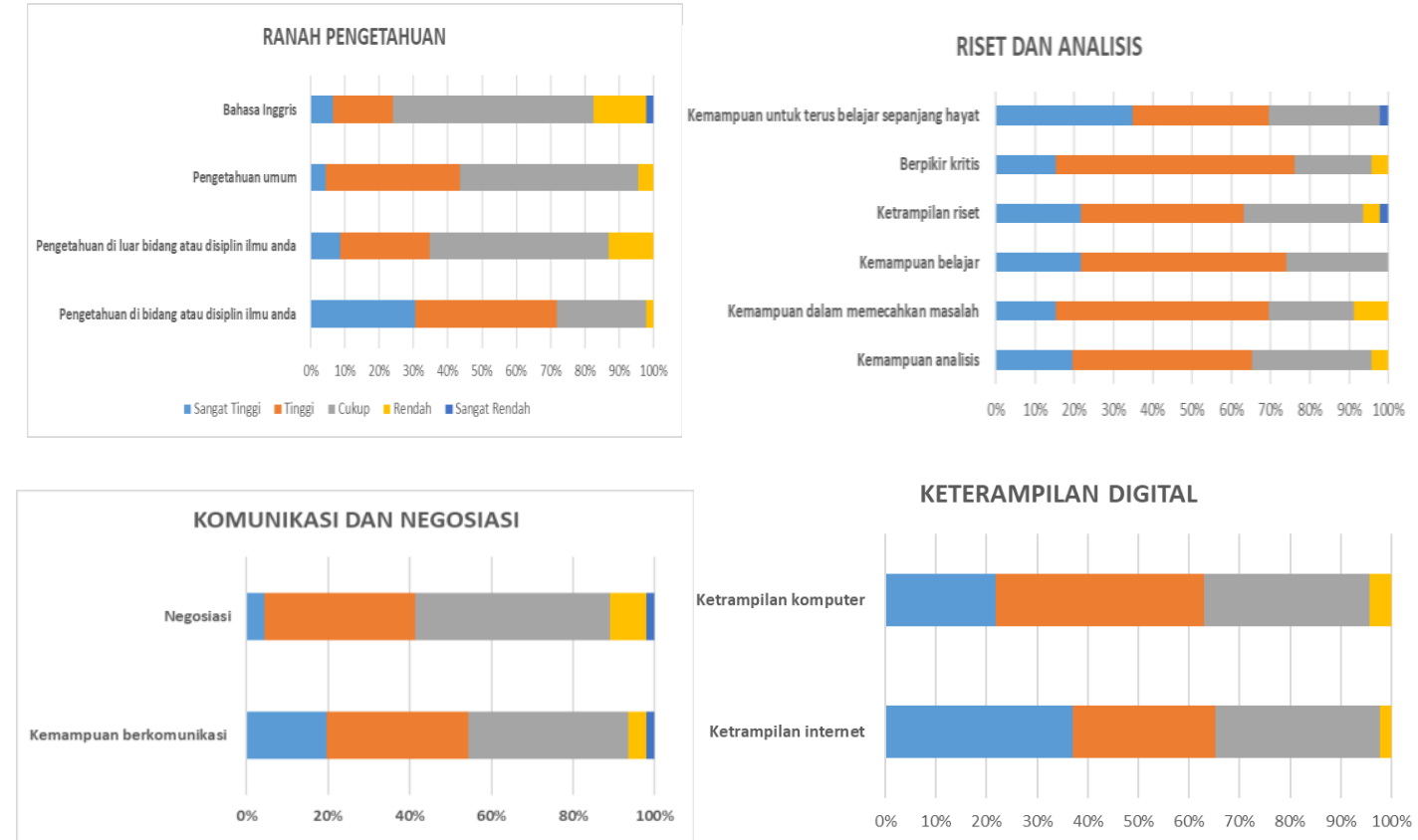

KEMAMPUAN BEKERJA

KEMAMPUAN MANAJERIAL
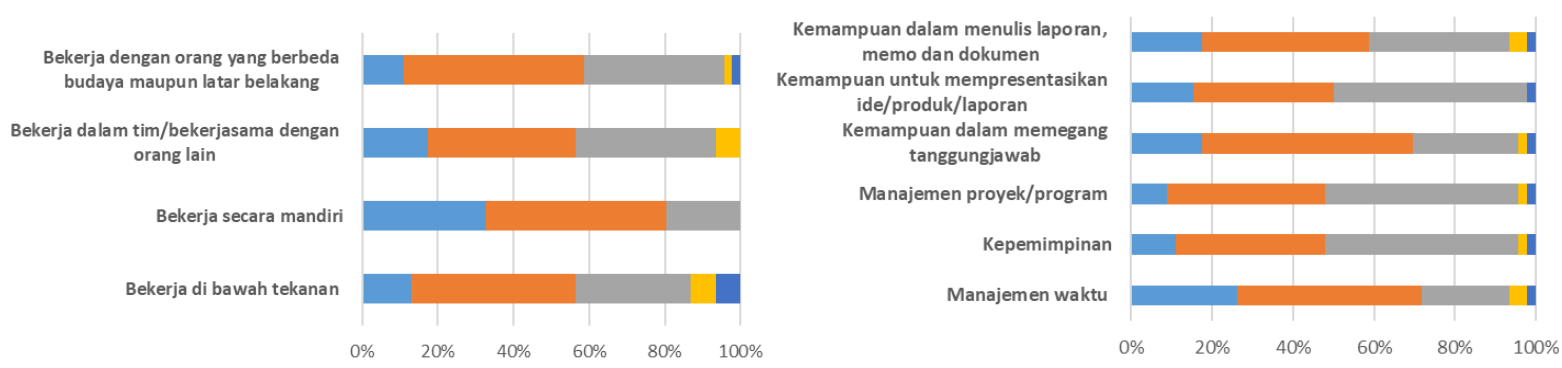


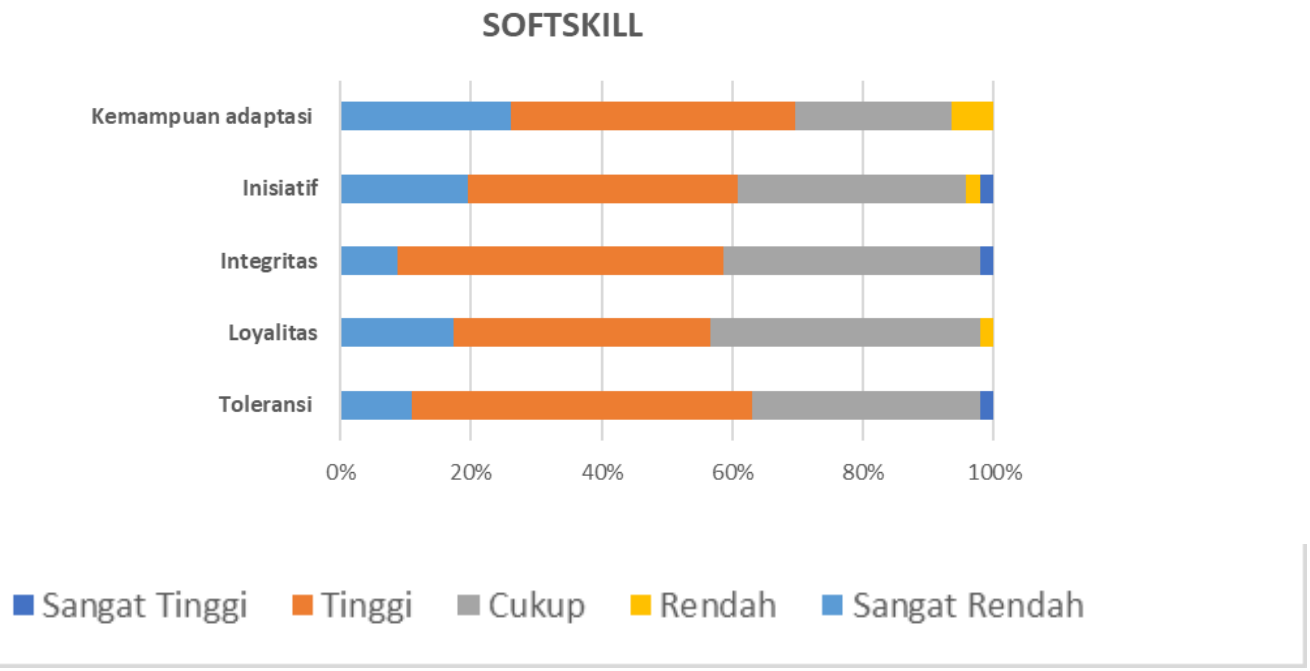

\section{Gambar 5}

Kontribusi Perguruan tinggi terhadap tingkat kompetesi yang dikuasai

\section{Kepuasan Alumni Terhadap Kualitas Layanan}

Program Studi Teknologi Pangan UT memberikan berbagai layanan akademik seperti tutorial online, tutorial tatap muka, dan bahan ajar cetak. Menurut pendapat alumni, sebanyak $74 \%$ alumni menyatakan layanan tutorial online sangat baik dan baik, $20 \%$ cukup baik, dan $6 \%$ menyatakan kurang baik. Lebih lanjut dalam tutorial online alumni memberikan masukan antara lain perlunya peningkatan server, tampilan yang lebih menarik, penambahan video dan studi kasus, serta tutor yang perlu lebih aktif. Selain tutorial online, bantuan belajar yang disediakan UT dalam bentuk tutorial tatap muka. Sebanyak 35\% alumni tidak menggunakan layanan ini dan $75 \%$ lainnya menggunakan layanan ini. Alumni yang menyatakan tutorial tatap muka pelaksanaannya sudah sangat baik dan baik sebesar $43 \%$, cukup baik $35 \%$, dan $2 \%$ menyatakan kurang baik.

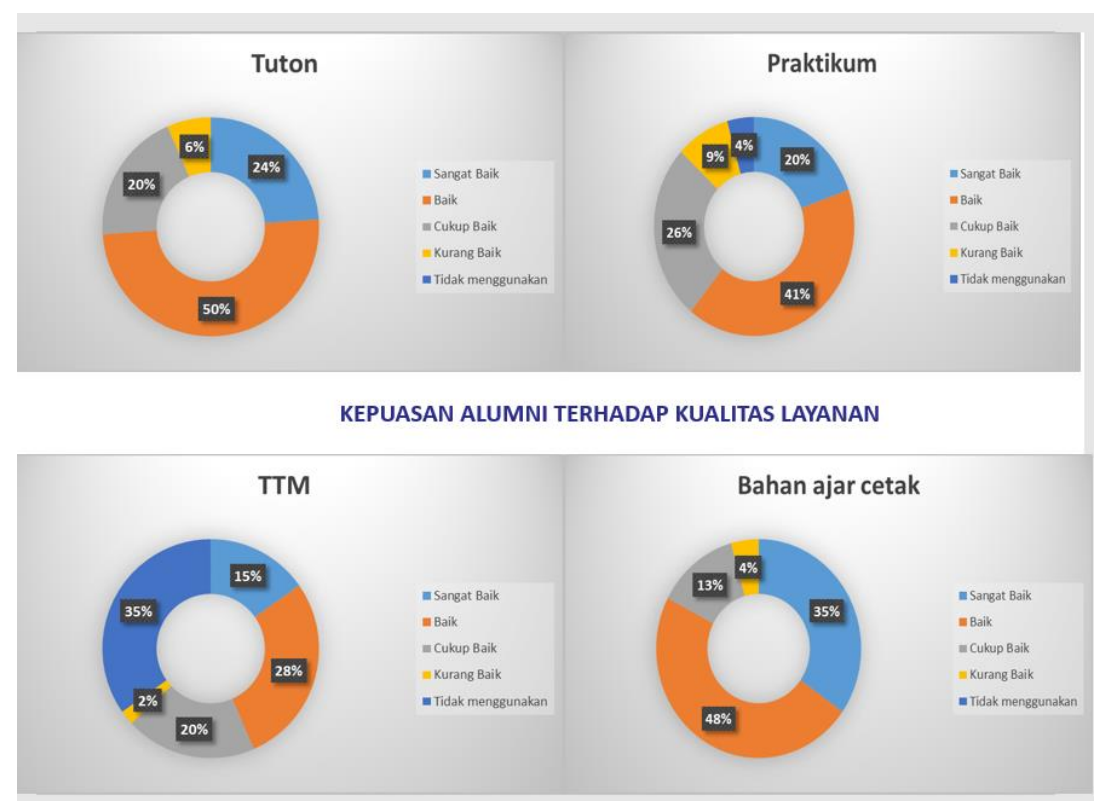

Gambar 6

Kepuasaan alumni terhadap layanan UT

Dini Nur Hakiki, Athiefah Fauziyyah, Eko Yuliastuti / Tracer Study Pada Program Studi S1 Teknologi Pangan Universitas Terbuka 
Selanjutnya dari segi praktikum, sebanyak 20\% alumni pelaksanaan praktikum menyatakan sangat baik, $41 \%$ baik, dan $26 \%$ cukup baik, $9 \%$ kurang baik, dan $4 \%$ tidak menggunakan. Dari persentase tersebut dapat dikatakan lebih dari $61 \%$ alumni menyatakan praktikum sudah dilakukan secara sangat baik dan baik. Masukan dari alumni untuk praktikum antara lain perlunya laboratorium sendiri yang dimiliki oleh UT sehingga tidak perlu bergantung kemitra, mata kuliah praktikum perlu diperbanyak dan tidak hanya dilakuakan di akhir semester, serta perlu integrasi mata kuliah praktikum dengan dengan mata kuliah lain. Dari segi bahan ajar cetak, sebanyak $48 \%$ alumni menilai bahan ajar sudah baik, $35 \%$ sangat baik, dan $13 \%$ cukup baik, serta $4 \%$ menyatakan kurang baik. Saran dari almni untuk bahan ajar cetak perlu dilakukan pembaharuan materi yang mengikuti dnegan perkemabanagn teknologi dan ilmu pengetahuan. Kepuasaan alumni terahdap layanan UT ditunjukan pada Gambar 6.

\section{KESIMPULAN}

Berdasarkan hasil tracer study program studi teknologi pangan 2017-2020 menyatakan bahwa dari segi keterserapan alumni di dunia kerja, alumni UT 68\% sudah bekerja dan sebanyak $70 \%$ sudah memperoleh pekerjaan sebelum masuk UT. Bidang pekerjaan alumni paling banyak di bidang swasta di sektor usaha makanan dan minuman. Kontribusi Perguruan tinggi terhadap tingkat kompetensi yang dikuasai alumni yaitu lebih dari $50 \%$ alumni menyatakan perguruan tinggi berkontribusi sangat tinggi dan tinggi dalam pengetahuan di bidang ilmu teknologi pangan, kemampuan riset dan analisis, komunikasi, ketrampilan digital, manajemen waktu dan kemampuan dalam memegang tanggung jawab, serta sof skill. Penilaian alumni terhadap metode pembelajaran di PS Teknologi Pangan.yaitu lebihd ari 50\% menyatakan sudah sangat baik dan baik dari tutorial online, praktikum, dan bahan ajar cetak. Masukan alumni untuk perbaikan layanan yaitu untuk tutorial online perlunya peningkatan server, tampilan yang lebih menarik, penambahan video dan studi kasus, serta tutor yang perlu lebih aktif, untuk praktikum yaitu perlunya laboratorium sendiri yang dimiliki oleh UT, mata kuliah praktikum perlu diperbanyak, serta integrasi mata kuliah praktikum dengan dengan mata kuliah lain, dan untuk untuk bahan ajar cetak perlu dilakukan pembaharuan materi yang mengikuti dnegan perkemabanagn teknologi dan ilmu pengetahuan. 


\section{DAFTAR PUSTAKA}

Adib, H. Mohammad. (2011). Filsafat Ilmu: Ontologi, Epistemol ogi, Aksiologi, dan Logika IImu Pengetahuan. Pustaka Pelajar.

Bakhri, Syaeful, \& Jumena, Juju. (2019). Dari Kampus Perjuangan untuk Indonesia. CV. Elsi Pro.

Dini, Dini, Fauziyyah, Athiefah, \& Yuliastuti, Eko. (2020). Tracer Study Pada Program Studi S1 Teknologi Pangan Universitas Terbuka. Jurnal Pendidikan Terbuka Dan Jarak Jauh, 21(1), 1-10.

Hartinah, Hartinah, \& Abdullah, Suparman Ibrahim. (2019). Pengaruh minat baca dan persepsi atas perpustakaan sekolah terhadap keterampilan menulis narasi. Diskursus: Jurnal Pendidikan Bahasa Indonesia, 1(02), 127-135.

Nasir, Muhammad, \& Rijal, Muhammad Khairul. (2020). Model Kurikulum Dan Pembelajaran Ma'had Al-Jami'ah Perguruan Tinggi Keagamaan Islam (Ptki) Di Indonesia.

Pasi, Ida Royani. (2019). Pengaruh Pengetahuan Dan Sikap Terhadap Perilaku Masyarakat Pada Bank Syariah. Jurnal Al-Qasd Islamic Economic Alternative, 1(2), 189-201.

Terkemuka, Perguruan Tinggi Islam, Unggul, Terpercaya, \& pada Tahun, Mandiri. (2016). Peningkatan Mutu dan Relevansi Perguruan Tinggi Melalui Tracer Study.

(C) 2020 by the authors. Submitted for possible open access publication under the terms and conditions of the Creative Commons Attribution (CC BY $\mathrm{SA}$ ) license (https://creativecommons.org/licenses/by-sa/4.0/) 